\title{
ORIGENS HISTÓRICAS DAS POLÍTICAS DE FORMAÇÃO DE PROFESSORES NO BRASIL (1823-1874)
}

Paulo Sergio Marchelli(*)

\section{INTRODUÇÃO}

Neste artigo apresentamos um estudo histórico sobre a formação de professores no Brasil, de forma a abranger desde a criação da Escola de Primeiras Letras na Corte Imperial em 1823 para instrução dos soldados do exército até o ano de 1874, quando se deu a fundação da Escola Normal na Capital da Província de São Paulo. Procuramos mostrar como ao longo do período estudado as políticas voltadas para a formação de professores atendiam a demandas específicas das classes dominantes do Estado monárquico, que tinham em vista a instrução elementar da população predominantemente pobre e analfabeta como reforçamento da transição de um sistema econômico ainda estritamente escravocrata e colonial em direção ao mercantilismo capitalista.

No plano da produção historiográfica, o objetivo do estudo é apresentar a genealogia da escola normal brasileira e com isso fazer a análise das conexões que se deram ao longo do período estudado entre currículo e formação de professores. No entanto, pretende-se focar também as dificuldades metodológicos da pesquisa no campo, ou seja, busca-se mostrar como as fontes primárias da História da Educação que têm servido à análise sobre a fundação das políticas de formação de professores em nosso solo merecem ser reinterpretadas para corrigir inúmeros fatos pouco esclarecidos pelas fontes secundárias, de forma que procuramos apontar e discutir criticamente os problemas que encontramos em vários textos consultados. Para tanto, valemo-nos da perspectiva teórico metodológica de Michel Foucault, que mostra por meio de um jogo de palavras como a história em nossos dias transforma os "documentos em monumentos" e com isso produz interpretações como desdobramentos de uma massa de dados que devem ser isolados e depois agrupados, olhados individualmente e depois inter-relacionados, tratados separadamente e depois organizados em conjuntos (FOUCAULT, 2008). Valemo-nos também das ideias de Jacques Le Goff, para quem Foucault propõe uma filosofia inédita voltada à moderna metodologia da

\footnotetext{
${ }^{(*)}$ Paulo Sergio Marchelli. Doutor em Educação pela Universidade de São Paulo. Professor do Departamento de Educação do Campus Professor Alberto Carvalho e do Programa de Pós-graduação em Educação da Universidade Federal de Sergipe. E-mail: paulomarchelli@hotmail.com.
} 
análise histórica, onde cada tipo de fonte passa a ter um tratamento diferenciado no cerne de uma estrutura de conjunto (LE GOFF, 1990).

Com este trabalho, ao olhar para as fontes de pesquisa utilizando o método de análise adotado esperamos ter conseguido acrescentar elementos significativos à história da formação de professores no Brasil, de forma a trazer novas informações sobre fatos ainda pouco conhecidos.

\section{AS ESCOLAS DE PRIMEIRAS LETRAS E O PROBLEMA DA ORIGEM DAS POLÍTICAS DE FORMAÇÃO DE PROFESSORES NO BRASIL}

A História da Educação ainda haverá de fornecer interpretações mais concisas sobre o problema da gênese das políticas de formação de professores no Brasil. Segundo Saviani (2009, p. 144), "é na Lei das Escolas de Primeiras Letras, promulgada em 15 de outubro de 1827, que essa preocupação apareceu pela primeira vez". Por meio desta Lei, o Imperador D. Pedro I sancionou o Decreto da Assembleia Geral que "manda criar escolas de primeiras letras em todas as cidades, vilas e lugares mais populosos do Império" (BRASIL IMPÉRIO, 1878, p. 71). O Decreto da Assembleia Geral assinado por D. Pedro I definia também que o trabalho dos professores dentro das escolas de primeiras letras seria realizado mediante a adoção de um procedimento pedagógico específico, o ensino mútuo ou método lancasteriano, que se tornou oficial em todo o Império.

O método lancasteriano, também chamado sistema monitorial foi criado por Andrew Bell e Joseph Lancaster na Inglaterra do final do Século XVIII e início do XIX, que passava por um processo acelerado de industrialização e produziu uma ampla concentração populacional urbana. Segundo Castanha (2012), o objetivo político do método era baratear a instrução das classes mais pobres por meio da optimização do trabalho do professor, de forma que este pudesse ensinar a uma grande quantidade de alunos ao mesmo tempo em que mantinha controle sobre o progresso dos mesmos. O professor ensinava a matéria primeiramente para um conjunto de alunos selecionados entre os mais aptos e organizava os demais em pequenos grupos, que eram instruídos pelos que já tinham aprendido. O sistema era controlado por uma disciplina rigorosa, em que cada aluno tinha um lugar definido pelo seu nível de conhecimento e mudava de posição em relação aos demais à medida que progredia nas lições. O método foi difundido para além das fronteiras inglesas e levado à França, Portugal, Suíça, regiões que constituiriam futuramente a Alemanha, Itália, Estados Unidos, Brasil e ainda outros países.

Inspirada na Constituição de 1824, que evocava os princípios da liberdade de ensino e instrução primária gratuita para todos, a Lei das Escolas de Primeiras Letras cumpriu um papel de reformulação do sistema educacional brasileiro, que se encontrava em uma situação totalmente 
desorganizada. Em momentos históricos anteriores, entre os anos de 1750 e 1777, Marquês de Pombal, o primeiro-ministro português inspirou-se em ideias iluministas para realizar reformas administrativas, econômicas e sociais tanto na metrópole quanto nas colônias portuguesas. Conforme apontado em Maciel \& Neto (2006, p. 465), “a reforma pombalina foi desastrosa para a educação brasileira e, em certa medida, também para o sistema educacional português". Desde a expulsão dos jesuítas promovida em 1759 como parte daquela reforma, até a vinda da corte portuguesa para o Brasil em 1808, nenhuma iniciativa política conseguiu substituir a excelente organização do sistema jesuítico, que se encontrava disseminado em todas as regiões litorâneas e se espalhava pelas matas e o planalto. As Aulas Régias implantadas por Pombal em substituição ao método de instrução baseado na Ratio Studiorum jesuítica nivelaram por cima os chamados estudos menores e não conseguiram promover a alfabetização elementar (BOTO, 2010). "Um empecilho para a realização dos objetivos pretendidos por Pombal foi a falta de homens capacitados para o ensino elementar e primário, verificando-se uma carência de professores aptos a ensinar [...]" (RIBEIRO, 2015, p. 423). Em 1777, só havia dois professores capacitados na Bahia, de forma que o sistema das aulas régias "consentiu que pessoas semianalfabetas ministrassem matérias sem qualificação, inclusive pedagógica" (OLINDA, 2003, p. 158). Ribeiro (2015, p. 423) destaca que "a capacitação dos professores para dar essas aulas foi majoritariamente precária, pois os docentes apresentavam um desconhecimento pedagógico e uma ignorância dos próprios conteúdos que ministravam". Em 1808, a vinda da corte portuguesa para o Brasil não foi menos pior em relação ao ensino elementar, pois Dom João VI preocupou-se prioritariamente com a elite letrada.

Com a derrota das tropas napoleônicas pelo exército inglês, Dom João VI retornou a Portugal em abril de 1821 e deixou para a elite cultural e econômica que se formou no Brasil a missão de proclamar a independência e empossar seu filho como Imperador. Segundo Siqueira (2006, p. 399), “o Império do Brasil foi uma denominação construída a partir de uma trama de interesses que remontava ao processo colonizatório e à ilustração portuguesa". Sabe-se que a sagração de Dom Pedro I como Imperador foi o arranjo encontrado pelos diversos grupos dominantes, cuja origem remonta às capitanias hereditárias que foram transformadas em províncias no dia 28 de fevereiro de 1821, para assegurar a integridade da coroa portuguesa e garantir a continuidade da escravidão. Consolidada a Independência, a força política das províncias dentro do Estado imperial passou a depender da quantidade de escravos que elas detinham e de como controlavam a massa da gente pobre, parda e negra livre, que causava grande temor nas elites. Esta "populaça" marginalizada não participava dos órgãos do governo e dos partidos políticos, mas exerceu grande pressão sobre a classe dominante e foi uma força expressiva na configuração do 
Império brasileiro. Para se proteger, as elites armaram os homens pobres e resolveram que os filhos dos mesmos deveriam ser educados, o que levou à reformulação do sistema de instrução primária herdada da Colônia e à adoção do método de ensino mútuo como melhor forma de reproduzir em curto prazo os interesses dos grupos imperiais dominantes.

Assim, a Lei das Escolas de Primeiras Letras exprime no âmbito educacional a consolidação do novo poder político instalado no Brasil com a Proclamação da independência. Trata-se do documento básico citado por vários pesquisadores da História da Educação brasileira como demarcação da primeira política de formação de professores no Brasil. No entanto, alguns setores da pesquisa histórica têm levantado que esta política é de fato anterior e já aparece no Decreto Imperial de $1^{\circ}$ de março de 1823 (BRASIL IMPÉRIO, 1887a), que cria uma Escola de Primeiras Letras na Corte para a instrução elementar dos novos soldados do exército recrutados das classes iletradas. O fato é que logo a seguir a este Decreto, em 29 de abril de 1823 é promulgada a Decisão Imperial 69 (BRASIL IMPÉRIO, 1887b), estabelecendo que as corporações militares das Províncias deveriam destacar soldados aptos a aprenderem o método na Escola da Corte, sob a forma do que contemporaneamente corresponde a um estágio. Depois, estes soldados replicariam o método em escolas criadas nas Províncias. Dessa forma, a Lei das Escolas de Primeiras Letras de Outubro de 1827 representaria o passo posterior das supostas políticas de formação implícitas nos documentos de 1823.

As interpretações históricas divergentes em torno dos primeiros documentos referentes à formação de professores são bastante frequentes. Em consideração a Saviani (2009), seria correto afirmar que a Lei das Escolas de Primeiras Letras de Outubro de 1827 é o instrumento político no qual a questão aparece pela primeira vez. Em consideração aos autores que argumentam o assunto ter sido colocado anteriormente pelo Decreto Imperial de $1^{\circ}$ de março de 1823, destaca-se: “Acredita-se que, oficialmente, a primeira escola pública de ensino mútuo tenha sido criada em $1^{\circ}$ de março de 1823, a qual se constituiu numa espécie de escola normal, voltada para preparar professores, especialmente militares" (CASTANHA, 2012, p. 4). No texto original do Decreto encontra-se:

Convindo promover a instrução em uma classe tão distinta dos meus súbditos, qual a da corporação militar, e achando-se geralmente recebido o método do Ensino Mutuo, pela facilidade e, precisão com que desenvolve o espírito, e o prepara para aquisição de novas e mais transcendentes idas: Hei por bem mandar criar nesta Corte uma Escola de primeiras letras, na qual se ensinará pelo método do ensino mutuo, sendo em benefício não somente dos militares do Exército, mas de todas as classe dos meus súbditos que queiram aproveitar-se de tão vantajoso estabelecimento. (BRASIL IMPÉRIO, 1887a, p. 41-2) 
Pelo que se lê no Decreto, à primeira vista parece que a interpretação de Castanha (2012) é procedente ao considerar que a escola de primeiras letras criada em $1^{\circ}$ de março de 1823 tenha algo a ver com a preparação de professores. No entanto, os militares do exército e as classes dos súditos do Imperador em benefício dos quais as escolas estavam sendo criadas referem-se aos alunos que nelas ingressariam para se alfabetizarem e não para serem formados como professores. O Decreto foi editado devido à condição precária da instrução pública em terras brasileiras na época em que o exército instalado pelo Estado imperial deveria garantir a consolidação da Independência e para tal precisasse incorporar ações crescentes de instrução escolar entre os soldados e oficiais inferiores. Conforme esclarece Alves (2016), a fabricação de novos materiais bélicos foi melhorada pela Revolução Industrial ocorrida entre as décadas dos anos 1760 a 1840, que produziu armas leves, de maior alcance e manuseio rápido, o que por sua vez exigiu uma valorização crescente da escolarização e elevação da capacidade intelectual como componentes básicos da formação militar.

$\mathrm{Na}$ verdade, pouco ou quase nada se sabe com exatidão a respeito do nível de letramento dos soldados e oficiais de baixa patente do exército imperial brasileiro na década dos anos de 1820. Mas se pode inferir que o analfabetismo entre tais classes de militares fosse muito alto, desde que o primeiro censo demográfico realizado no Brasil em 1872 apontou que apenas 17,7\% da população de 5 anos ou mais de idade era alfabetizada, entendendo-se por isso saber assinar o próprio nome (FERRARO, 2002). A análise regressiva dos dados censitários aponta que nas décadas anteriores aos anos 1870 as taxas de analfabetismo da população de 5 anos ou mais variaram em torno do elevado patamar de 80\% (MARCHELLI, 2006). No caso do Exército, este "era relativamente despreparado, com uma organização de estrutura precária, comandantes inaptos e comandados compostos por indivíduos das classes mais baixas, que eram consideradas como perigosas" (LARA, 2014, p. 4). O alistamento militar obrigatório era visto na representação do imaginário da época como um "tributo de sangue" imposto aos despossuídos pelas classes dominantes, que nada mais podiam cobrar do que a própria vida dos dominados. O significado de tributo de sangue foi explorado por Beattie (2009) em seu livro homônimo, para descrever as práticas forçadas de conscrição pelo Estado, com vistas a combater a criminalidade dos pobres, que uma vez alistados no exército desenvolveriam a identidade nacional, a cidadania e a honra.

A suposição de que a Escola de Primeiras Letras da Corte desempenhou uma política elementar de formação de professores baseia-se na interpretação da Decisão 69, de 29 de abril de 1823, por meio da qual S. M. o Imperador determina que a Secretaria de Estado dos Negócios da Guerra solicite aos governos das províncias que 
[enviem] para esta Corte um ou dois indivíduos tirados da Tropa de Linha, sejam da classe dos Oficiais Inferiores, sejam dos soldados, que tenham a necessária e conveniente aptidão, para aprenderem o mencionado método [de Lancaster], e poderem voltando à sua Província dar lições não só aos seus Irmãos d'Armas, mas ainda às outras classes de cidadãos. (BRASIL IMPÉRIO, 1887b, p. 52).

Assim, a partir dos dois documentos vistos em conjunto, o Decreto e a Decisão, infere-se que neles reside a gênese da política inquerida. Pode-se afirmar que o Decreto e a Decisão imperiais de 1823 referidos complementaram-se no sentido de que no mês de março é criada na cidade do Rio de Janeiro onde se situava a Corte uma escola de Primeiras Letras baseada no ensino mútuo, para a qual no mês de abril ficou estabelecido que os Governos provinciais enviassem de um a dois soldados ou oficiais de baixa patente para aprenderem sobre o método. Portanto, parece crível que o Decreto e a Decisão conjuntamente, mas não somente o primeiro como Castanha (2012) acredita estabeleceram pela primeira vez uma política de formação de professores no Brasil, o que implica definitivamente na desrazão de Saviani (2009) em afirmar que tal preocupação surgiu somente com a Lei das Escolas de Primeiras Letras promulgada em 15 de outubro de 1827. Portanto, a fundação das políticas voltadas para a formação de professores no Brasil ter-se-ia dado já nos momentos iniciais do Império.

No entanto, o processo formativo não possuía um currículo específico, pois o papel dos futuros professores aprendizes resumia-se a observar dentro da Escola de Primeiras Letras da Corte o método por meio do qual a escolarização dos alunos funcionava. Provavelmente, os professores aprendiam o método lancasteriano pela observação direta dos alunos em atividade e parece que não havia espaço para a discussão pedagógica. A Lei das Escolas de Primeiras Letras de 1827 vai atingir um público muito maior e ampliar a sistematização da instrução básica para além dos quartéis militares, de forma que o suposto processo de formação de professores associado ao ensino mútuo se expande para todas as capitais provinciais. Esta pretendida forma elementar de preparar professores com base na observação direta de como os alunos deveriam ser organizados em sala de aula para facilitar a ação monitorial entre os mesmos se fez presente durante todo o período imperial, mediada por uma paulatina e lenta transformação que decorreu da adoção a partir de 1835 do modelo das escolas normais europeias (ALVES, 2016; SAVIANI, 2009; CASTANHA, 2007, 2008a, 2008b, 2012; SCHUELER, 2005).

Porém, mesmo que com base na análise dos documentos oficiais haja acordo entre os historiadores da educação sobre o fato de que o ensino mútuo foi a tônica das primeiras políticas de formação no Brasil, a interpretação sobre as práticas de como o processo formativo se dava é 
interessantemente controversa. Schaffrath (2008), por exemplo, admite que mesmo pouco se conheça a respeito da história da formação docente no Brasil, os documentos oficiais revelam que:

[...] muito antes que se fundassem as primeiras instituições destinadas a formar professores para as escolas primárias, já havia, por parte dos governos, a preocupação com a qualidade do ensino na Corte e nas Províncias. Até que as preocupações em torno de uma formação docente específica ganhassem consistência, os mestres se preparavam enquanto se alfabetizavam nas Escolas de Primeiras Letras. Eram, a maioria delas, escolas de ensino mútuo, ou seja, aplicavam o Método Lancaster, onde o professor tomava um ou mais alunos para monitorá-lo e estes aprendiam o oficio ajudando o professor nas tarefas com os demais. Este sistema garantia a formação docente e, ao mesmo tempo, a propagação do método. [...]. De fato, o Método Lancaster era praticado em muitas escolas no Brasil, e como não existiam ainda as escolas de formação docente, os professores aprendiam o ofício, muitas vezes enquanto ainda eram alunos de cursos primários que utilizavam o referido método. (SCHAFFRATH, 2008, p. 145).

Nesse caso, é nos monitores do ensino mútuo que o autor enxerga os futuros professores, mas essa perspectiva é sem dúvida polêmica. Novamente, a interpretação não é condizente com o que se encontra no Decreto Imperial de $1^{\circ}$ de março de 1823 e na Decisão 69 de 29 de abril do mesmo ano, que juntamente com a Lei de 15 de outubro de 1827 constituem os principais documentos oficiais dos quais são feitas as inferências sobre a questão do ensino mútuo como processo de formação de professores no início do Império. Primeiramente, o Decreto Imperial explicita que as escolas de primeiras letras criadas na Corte destinavam-se aos súditos em geral e à corporação militar em particular. Nada há no documento que indique serem os súditos e militares alfabetizados e ao mesmo tempo preparados como futuros mestres. A seguir, a Decisão 69 de 29 de abril de 1823 torna claro que um ou dois oficiais inferiores e soldados seriam tirados da tropa de linha e enviados à corte para aprenderem o método de Lancaster e não para se alfabetizarem, tanto que, reza o documento, os militares destacados deveriam apresentar antecipadamente aptidão para quando voltarem às suas províncias darem lições não apenas aos seus companheiros de armas mas também aos demais cidadãos. Finalmente, a lei de 1827 determina que as escolas de ensino mútuo seriam criadas sob a responsabilidade das províncias, de forma que os professores já em exercício que não conhecessem o método lancasteriano deveriam ir aprendê-lo nas capitais. Assim, a interpretação a partir das fontes citadas de que nas escolas de primeiras letras mestres eram preparados enquanto se alfabetizavam demonstra ser uma ilação duvidosa, que se torna difícil de sustentar como fato concreto.

Parece que a inferência de Schaffrath (2008) decorre de uma visão sobre o papel dos monitores nas escolas de ensino mútuo induzida pela ideia de que os mesmos poderiam se formar como mestres ao ajudarem nas tarefas com os demais alunos. Segundo Abbagnano \& Visalberghi 
(1964, p. 450), o lema de Lancaster era "um só mestre para mil discípulos", de forma que numa típica escola de ensino mútuo ou de "monitores", os alunos que poderiam exceder a várias centenas eram divididos em muitas "classes" ou grupos diversos para a leitura e a escrita, por uma parte, e para a aritmética, por outra. O aluno mais capaz de cada classe ou fração de classe, denominado “monitor”, era instruído separadamente pelo mestre para que, por sua vez, ensinasse os demais companheiros. Mesmo que eventuais monitores se tornassem mais tarde mestres, não é possível encontrar princípios de formação docente implícitos no processo pedagógico das escolas de primeiras letras, pois isso exigiria uma visão disciplinar totalizante que, claramente, não era seu objetivo.

Assim, os impasses existentes nas pesquisas históricas sobre a origem da formação de professores no Brasil são frutos de uma interpretação pouco concisa das fontes documentais quanto ao papel do ensino mútuo adotado pelas escolas de primeiras letras do início do Império. Para corrigir as distorções interpretativas encontradas, deve-se evitar a inconsistência da ideia de que em tais escolas os mestres eram preparados ao mesmo tempo em que se alfabetizavam, crença presente de forma ametódica na história da educação brasileira. Em outras palavras, será preciso evitar a afirmação controversa de que as escolas de primeiras letras baseadas no ensino mútuo cumpriam além da instrução elementar a tarefa precípua de formar professores. Estas escolas, como se vê, foram criadas para tornar coerente a instrução elementar em um império de analfabetos, que precisava se apressar para encontrar condições de estabelecer-se mesmo que tardiamente dentro do mercantilismo internacional. Pode-se alegar a favor da correção proposta à interpretação histórica que somente há coerência em considerar uma política educacional como propriamente voltada para a formação de professores quando a questão curricular para tal propósito estiver posta explicitamente, o que se dará por meio das escolas normais que surgiram na Europa no final dos anos Setecentos e que depois foram trazidas ao Brasil a partir da terceira década dos Oitocentos.

\section{AS PRIMEIRAS ESCOLAS NORMAIS E O ADVENTO DA ASSOCIAÇÃO ENTRE CURRÍCULO E FORMAÇÃO}

No Brasil Império, em 12 de agosto 1834, foi publicada pela Regência Trina Permanente a Lei $\mathrm{n}^{\circ} 16$, decorrente de um acordo entre liberais e conservadores das elites dominantes com vistas ao controle do poder político central. Segundo o art. 10, $\S 2^{\circ}$ desta Lei, “compete às Assembleias Legislativas provinciais legislar sobre instrução pública e estabelecimentos próprios a promovê-la, [...]” (BRASIL IMPÉRIO, 1866, p. 17). Com isso, "começaram a surgir escolas de formação de professores em algumas províncias, como no caso da fluminense, que ganhou uma escola normal 
em Niterói, em 1835” (GABLER, 2016, p.1). Esta teria sido a primeira escola normal brasileira, mas há controvérsias entre os pesquisadores em relação à interpretação do documento da Província do Rio de Janeiro que a criou. Em Castanha (2008a, p. 19) e Castanha (2008b, p. 3) encontra-se: “[...] a Província do Rio de Janeiro criou a primeira Escola Normal do Brasil, em Niterói, através da Lei n. 10, de 4 de abril de 1835". Já Martins (2009, p. 177) cita o mesmo documento para dizer que: “em 1835, no município de Niterói, promulgou-se a Lei $\mathrm{n}^{\circ} 10$ que organizou o ensino normal e estabeleceu as normas para aqueles que pretendiam se candidatar a escola Normal". A polêmica está em que os dois autores referem-se à mesma Lei como possuindo fins diferentes, o primeiro assumindo que ela "cria uma Escola Normal na Capital da Província do Rio de Janeiro" (CASTANHA, 2008a, p. 34; 2008b, p. 15) e o segundo afirmando que ela "dispõe sobre a organização do ensino normal e estabelece as normas de ingresso nesta modalidade de ensino" (MARTINS, 2009, p. 181). Parece que o primeiro autor se engana quanto à finalidade do documento porque sua fonte primária citada, a Coleção de Leis, Decretos e Regulamentos da Província do Rio de Janeiro desde 1835, publicada em 1839 pela Tipografia Niterói (PROVÍNCIA DO RIO DE JANEIRO, 1839) talvez tenha compilado erroneamente o apontamento legal original. Mesmo diante da possibilidade de que outras compilações do documento original também atuem como falsas fontes, tudo indica que a criação da Escola Normal de Niterói deu-se não por meio de uma Lei, citada como a de $n^{\circ} 10$, de 4 de abril de 1835, mas sim pelo Decreto de mesmo número daquele ano, publicado no dia 10 de abril. Assim, neste Decreto, Joaquim José Rodrigues Torres, Presidente da Província do Rio de Janeiro sanciona uma Carta de Lei em que manda executar a decisão da Assembleia Legislativa Provincial que cria uma escola normal em Niterói: "Haverá na Capital da Província do Rio de Janeiro uma Escola Normal para nela se habilitarem as pessoas, que se destinarem ao magistério de instrução primária [...]" (PROVÍNCIA DO RIO DE JANEIRO, 1835 , art. $\left.1^{\circ}\right)$.

Portanto, a fonte de Martins (2009) quanto à finalidade Lei 10, de 4 de abril de 1835, que de fato não criou a escola normal de Niterói é mais aceitável, mesmo que a referência bibliográfica do autor esteja fora das normas. Sucede que ele não especifica a origem da publicação na referência, apresentando-a da seguinte forma:

RIO DE JANEIRO. Lei 10, de 4 de abril de 1835. Dispõe sobre a organização do ensino normal e estabelece as normas de ingresso nesta modalidade de ensino. Rio de Janeiro, 1835. (MARTINS, 2009, p. 181).

A falta da informação sobre quem compilou um documento e o publicou contribui indubitavelmente para a necessidade de que a veracidade do mesmo seja discutida, de forma a fazer 
valer a prudência e evitar falsas interpretações históricas, fadadas a cair em descrédito. Assim, na dúvida, haverão de ser inquiridas as considerações de Martins (2009) sobre as determinações da Lei 10 da Província do Rio de Janeiro de 4 de abril de 1835, mas a afirmação de que a criação da Escola Normal de Niterói não se deu por meio dela parece convincente. É aceitável, portanto, que o Decreto 10, da Província do Rio de Janeiro de 10 de abril de 1835, deva ser considerado como o marco fundador da primeira escola normal pública de formação de professores no Brasil. A partir de então, um movimento de descontinuidade perpassou a formação de professores do ensino elementar e somente no final do Império as escolas formadoras se arrimaram em várias localidades, muitas sendo instaladas, mas poucas iniciando efetivamente suas atividades (ESCOLAS NORMAIS, 2016). Elas funcionavam por algum tempo, fechavam e reabriam posteriormente em um círculo ininterrupto. Em Minas Gerais, foram instaladas nove escolas normais antes do início da República: a de Ouro Preto e a de Campanha em 1872; a de Diamantina e de Paracatu em 1879; Montes Claros em 1879; Sabará em 1881; Uberaba, Juiz de Fora e São João Del-Rei em 1884.

O movimento de descontinuidade empreendido pelas escolas normais desde sua fundação exige que o estudo de suas fontes seja realizado com rigor e torna oportuno perguntar: Porque muitos autores que contemplam as escolas normais do ponto de vista histórico encontram dificuldades em relação não somente à interpretação das fontes, mas também para discutir problemas de compilação, como o caso aqui apontado da Coleção de Leis, Decretos e Regulamentos da Província do Rio de Janeiro? Uma das razões é certamente a falta da leitura de Michel Foucault, que mostra como os métodos da análise histórica contemporânea precisam transformar os documentos em "monumentos" para conseguirem "materializar" o passado por meio de uma leitura "arqueológica" das fontes: “[...] poderíamos dizer, jogando um pouco com as palavras, que a história, em nossos dias, se volta para a arqueologia - para a descrição intrínseca do monumento" (FOUCAULT, 2008, p. 8). Isso significa que dados os problemas interpretativos existentes sobre o surgimento das escolas normais no Brasil, será preciso realizar o movimento foucaultiano de olhar para os documentos como "monumentos arqueológicos", resultantes de um processo de "coleta e escavação", que permite compreender a História por meio da materialização das suas fontes como espécies de "artefatos fósseis".

Para Le Goff (1990), Foucault produziu uma excepcional viragem no estudo do período situado entre o final da Idade Média e o século XIX, pois ao trazer à tona a segregação dos loucos encerrados nos hospícios, dos doentes tratados nas clínicas, dos criminosos trancafiados nas prisões, dos costumes sexuais etc., produz um amálgama de elementos explicativos que isolados, depois agrupados, postos em relação e tornados eficazes, propõem uma filosofia original estritamente 
ligada à metodologia da moderna disciplina histórica. Com os novos métodos, "[...] cada tipo de fonte exige um tratamento diferente no interior de uma problemática de conjunto" (LE GOFF, 1990, p. 46). A problemática de conjunto aludida por Le Goff, no caso do estudo dos currículos das escolas normais brasileiras sob o ponto de vista histórico é interiorizada pela maioria dos autores apenas em termos das transformações sociais que criam as relações hegemônicas da sociedade, seus sistemas políticos, econômicos, educacionais, etc. Assim é que Almeida (1995), que tem sido o texto referente à história do currículo das escolas normais de maior acesso no Google e contém um elevado número de citações, constitui uma referência típica do espírito não foucaultiano da pesquisa na área. Tal texto estuda as primeiras escolas normais em São Paulo, sobre as quais a autora escreve:

As primeiras escolas normais caracterizavam-se pela precariedade dos programas e não apresentavam uma proposta pedagógica coerente com seus objetivos, e também não havia professores habilitados para lecionar nessas escolas. A primeira escola normal da província de São Paulo foi criada a 16 de março de 1846, pela Lei $n^{\circ} 34$. Do plano de ensino, constavam as disciplinas que o professor deveria ensinar no curso primário, sendo apenas uma, denominada Métodos e Processos de Ensino, de caráter pedagógico. As demais referiam-se àquelas que deveriam ser ensinadas no curso primário. Essa escola foi denominada Escola Normal Primária, com duração de dois anos, dirigida apenas aos alunos do sexo masculino, e apresentava o seguinte programa: [...] Lógica, Gramática Geral e da Língua Nacional, Teoria e Prática de Aritmética, Noções Gerais de Geometria Prática e suas Aplicações, Caligrafia, Princípios da Doutrina Cristã, Métodos e Processos de Ensino. (ALMEIDA, 1995, p. 666-7).

Para indexar a Lei citada pela autora em seu acervo eletrônico de consulta pela Internet (SÃO PAULO, [s. d.]a), a Assembleia Legislativa do Estado de São Paulo apresenta no sistema de busca a ementa de que ela "dá nova organização às escolas de instrução primária, e cria uma Escola Normal". No entanto, a parte da ementa referente à criação de uma escola normal não aparece textualmente em nenhum item da redação original do documento e provavelmente resulte de uma interpretação pouco criteriosa do texto, produzida não com o intuito de identifica-lo com precisão, mas sim de lançar uma informação obrigatória para a montagem do banco de dados do sistema. $\mathrm{O}$ que de fato esta Lei tem como objeto são a instrução primária e o estabelecimento das escolas para tal fim (Título $1^{\circ}$ ), a habilitação e o provimento dos professores (Título $2^{\circ}$ ), os vencimentos e aposentadorias dos professores públicos (Título $3^{\circ}$ ), a suspenção, remoção e demissão dos professores públicos (Título $4^{\circ}$ ), a inspeção das escolas e os exames dos alunos (Título $5^{\circ}$ ). A seguir vem o Título 6, em que aparece o artigo 31 a determinar na voz futura ao governo estabelecer uma escola normal na capital da Província, bem como as matérias para serem ensinadas. É interessante observar no Título 7, Das Disposições Gerais, a redação do Artigo que define as condições de 
contratação de professores não formados: “[...] enquanto não estabelecer-se a escola normal, e não houverem candidatos às cadeiras, formados na mesma, só se dará provimento provisório, e com dois terços do ordenado marcado na presente lei” (SÃO PAULO, [s. d.]a, art. 36).

O fato é que o objetivo da Lei provincial de 1846 em questão não foi especificamente criar uma Escola Normal na capital, mas sim estabelecer por meio dos cinco artigos do Título $6^{\circ}$ as regras básicas para quando isto vir a acontecer. Há um parágrafo nas Disposições Gerais que demonstra tal fato de forma muito clara:

O governo, no regulamento que organizar para execução da presente lei, determinará o programa dos exames tanto a respeito da escola normal, como das menores: a polícia e economia das escolas, os castigos, a duração diária dos exercícios, que não será menos de duas horas e meia de manhã, e outro tanto de tarde; estabelecerá o modo pratico da inspeção pelas comissões e especificadamente para a verificação do número de alunos que frequentam efetivamente as escolas; e dará todas as mais providencias que forem uteis e consentâneas com a presente lei, podendo cominar multas de vinte a sessenta mil réis, que serão impostas administrativamente, a todos os que forem incumbidos de qualquer ramo de serviço de instrução primaria, quando não cumpram a presente lei, e as instruções, e regulamentos do governo. (SÃO PAULO, [s. d.]a, art. 44).

Como se vê, a conjugação verbal do art. 44 é inteiramente no futuro, de forma a se entender que o "programa dos exames" da escola normal será regulamentado posteriormente. Este programa refere-se às provas internas aplicadas pela escola. Trata-se de uma sutileza que os acontecimentos posteriores estiveram longe de alcançar, inclusive antes de 1874 nenhuma regulamentação propriamente dita foi editada na Província para as escolas normais, de forma que a primeira destas surgiu às cegas e precipitadamente no mesmo ano de promulgação da Lei da Instrução Primária. “Uma Escola Normal destinada à preparação de professores de primeiras letras foi criada na cidade de São Paulo no ano de 1846, somente para meninos, com apenas um professor" (MARCÍLIO, 2001, p. 6-7). Segundo o Anuário do Ensino do Estado de São Paulo de 1907/1908, redigido por Rodrigues et al. (1908), o curso desta "primeira" escola normal era de dois anos, com o seguinte programa:

Gramatica geral e da língua nacional; Aritmética - teoria e pratica até proporções, inclusive; Geometria - noções gerais e aplicações usuais; Caligrafia; Logica; Religião - princípios de religião do Estado; Métodos e Processos de Ensino, sua aplicação e vantagens comparativas. (RODRIGUES et al., 1908, p. 79)

A escola foi instalada em novembro de 1846 em uma sala do edifício contiguo à Catedral da Sé, pertencente ao conjunto dos clérigos (Cabido). Seu primeiro professor. Dr. Manoel José Chaves, acumulava também o cargo de diretor e foi nomeado por um Decreto em 24 de outubro de 1846. 
Não havia um regimento interno e a instituição estava subordinada à superintendência da "Inspetoria Geral da Instrução Publica", à qual encaminhava relatórios. Funcionou pouco mais de 20 anos, até 10 de julho de 1867, data em que foi extinta pela Lei n 16 daquele mês e ano. "Pelos poucos dados existentes e que pudemos colher, pode-se inferir que a Escola Normal, nesta sua primeira fase, teve um só professor, o qual, tomando uma turma de alunos, os levava até o fim do curso, voltando depois a leccionar nova turma no $1^{\circ}$ ano" (RODRIGUES et al., 1908, p. 80). Os autores citam um relatório enviado à Inspetoria pelo Dr. Diogo de Mendonça, que explica na Escola Normal até o ano de 1855 terem se formado 18 alunos, uma média de dois por ano desde a fundação, portanto. Como o estabelecimento funcionou durante 20 anos, os autores conjecturam que nele se formaram desde sua fundação até a extinção mais ou menos quarenta professores.

Em 1855, o presidente da Província declara que a Escola Normal

[...] nenhuma utilidade tem prestado e de certo nada se podia esperar dela à vista dos vícios salientes com que foi estabelecida. [...]. O que há ali é análise gramatical, algumas operações de aritmética, certas explicações de religião e principalmente a lógica e a leitura tão superficial que em nada se aproveita. (MARCÍLIO, 2001, p. 7).

Em 1858, outro governador lamentava a situação da Escola Normal:

A Província não possui os prédios precisos, nem receita tão elevada que lhe seja dado mandálos construir... Ora, pagar mal ao magistério de primeiras letras e sobrecarregá-lo ainda, quer com o aluguel da sala para a escola, quer com a despesa de aquisição dos móveis e utensílios, sem os quais é impedida de funcionar, é fato sobremodo inadmissível”. (p. 7).

Assim, a primeira escola normal fundada na capital provincial de São Paulo não serviu para nada, isto no dizer do próprio Governador em 1855. Para convir a alguma coisa, seria preciso construir um monumento que realizasse sua materialização arqueológica, ou no conceber do Governador de 1858, ela deveria funcionar em uma instalação predial adequada. Mas não é só isso, pois entender a escola normal como monumento foucaultiano significa principalmente definir sua natureza organizacional pública e pedagógica enquanto instituição educacional, o perfil dos indivíduos que nela poderão se candidatar para ingresso, como seria financiada, quais são as matérias de ensino e de que forma as cadeiras se constituirão, os períodos de funcionamento, horários, regime de férias, a quem compete a direção, etc. Também é de importância fundamental indicar o perfil do magistério dedicado à escola normal, como os professores deverão ter se formado e quais as condições de sua admissão, de que forma a carreira docente é pensada, etc. Todos estes quesitos vão estar presentes na Lei 9, de 22 de março de 1874, cuja ementa elaborada pela atual Assembleia Legislativa do Estado de São Paulo para consulta eletrônica à sua base de dados indexa que esta Norma "estabelece o ensino primário gratuito na Província (SÃO PAULO, 
[s. d.]b). Mais um engano da Assembleia Legislativa paulista, pois seria preciso constar no indexador que a Lei também cria uma Escola Normal. Isto é matéria da Seção II, cujo $1^{\circ}$ Parágrafo estabelece: "Fica criada, nesta Capital, uma Escola Normal, para o fim de habilitar os indivíduos que se destinarem ao magistério da instrução primaria" (SÃO PAULO, [s. d.]b, art. $8 .^{\circ}, \S 1^{\circ}$ ). Observa-se que neste parágrafo a conjugação verbal está no particípio passado - fica criada, diferentemente do parágrafo correlato na Lei 34/1846, cujo verbo está no futuro do presente - “o Governo estabelecerá na capital da Província uma Escola Normal [...]”.

Esta Lei ementada de forma incompleta como se apenas estabelecesse o ensino primário gratuito na Província de São Paulo possui três seções que enumeram matérias distintas, a primeira referindo-se propriamente a tal ementa, a segunda inteiramente dedicada à criação da escola normal, a última tratando de aspectos político-administrativos das escolas primárias e princípios relacionados à carreira decente. A Seção I possui 7 artigos, alguns dos quais desmembrados em parágrafos, que contam ao todo 14 normas específicas; a Seção II apresenta 2 artigos, o primeiro deles com 15 parágrafos, onde cada um corresponde a uma norma específica e o outro com 2 parágrafos que obedecem à mesma correspondência; na Seção III aparecem 8 artigos, um deles com 2 parágrafos e o último a revogar disposições contrárias à lei, contando-se assim 9 normas específicas. Como se vê, a Seção sobre a criação da escola normal é a maior de todas, pois apresenta 17 normas específicas. A escola normal criada em São Paulo em 1874 foi fechada por ato do Presidente da Província datado de 9 de maio de 1878, o que se efetivou em 30 de junho daquele ano.

\section{CONSIDERAÇÕES FINAIS}

O desacerto existente na indexação pela Assembleia Legislativa de São Paulo da Lei 9/ 1874 da Província vai muito além do sentido incompleto da ementa produzida, pois o termo principal da Norma não parece ser a gratuidade do ensino primário, mas sim a sua obrigatoriedade:

O ensino primário é obrigatório para todos os menores de 7 a 14 anos do sexo masculino, e 7 a 11 do sexo feminino, que residirem dentro de Cidade ou Vila em que houver escola pública ou particular subsidiada, não tendo eles impossibilidade física ou moral. (SÃO PAULO, [s. d.]b, Seção I, Art. $1^{\circ}$ )

A gratuidade das escolas públicas já fora garantida pela Lei 34, de 16 de março de 1846: “O governo estabelece escolas públicas de instrução primaria em todas as cidades e vilas, e nas outras povoações que, atento o número da população reunida, julgar em circunstancias apropriadas, sujeitando à aprovação da assembleia”. (SÃO PAULO, [s. d.]a, art. 3. ${ }^{\circ}$ ). As escolas públicas sempre 
foram gratuitas em toda a História do Brasil, mas o ensino primário obrigatório na Província de São Paulo surge somente com a Lei 9 de 1874 e não com a no 34 de 1846, fato que a Assembleia Legislativa deveria rever em sua base de dados.

A falta de uma indexação criteriosa de documentos na era da disseminação da informação pela Internet é sem dúvida prejudicial à pesquisa, de forma que os historiadores da educação voltados para a escola normal no Brasil necessitam criar urgentemente procedimentos críticos no sentido de Foucault e Le Goff para enfrentarem esse problema. No caso, o método devido para a interpretação dos documentos indexados pela Assembleia Legislativa de São Paulo consistiria na crítica aos compiladores, que ao enfeixarem a legislação da Província numa única interface eletrônica para consulta produziram ementas enganosas. A partir destas ementas é que muitos pesquisadores inexperientes têm sido logrados em sua leitura e levados a interpretar incorretamente os fatos referentes ao surgimento da escola normal no Brasil. 


\section{REFERÊNCIAS}

ABBAGNANO, Nicola; VISALBERGHI, Aldo. Historia de la pedagogía. México: Fundo de Cultura Económica, 1964. $709 \mathrm{p}$.

ALMEIDA, Jane Soares. Currículos da Escola Normal Paulista (1846-1920): Revendo uma Trajetória. Revista Brasileira de Estudos Pedagógicos, Brasília, v. 76, n. 184, p. 665-689, set./dez. 1995.

ALVES, Cláudia M. Costa. A intelectualidade militar e as práticas escolares no exército brasileiro no século XIX. 2016. Disponível em: <http://www.sbhe.org.br/novo/congressos/cbhe2/pdfs/Tema3/3161.pdf>. Acesso em: 28 out. 2016.

BEATTIE, Peter M. Tributo de Sangue. São Paulo: EDUSP, 2009.

BOTO, C. A dimensão iluminista da reforma pombalina dos estudos: das primeiras letras à universidade. Revista Brasileira de Educação, Rio de Janeiro, v. 15, n. 44, p. 282-299, maio/ago. 2010.

BRASIL IMPÉRIO. Decreto de $1^{\circ}$ de março de 1823. Cria uma Escola de primeiras letras, pelo método do Ensino Mutuo para instrução das corporações militares. In Coleção das Leis do Império do Brasil de 1823 - parte II. Rio de Janeiro: Imprensa Nacional, 1887a. p. 41-2. Disponível em: <http://bd.camara.gov.br/bd/bitstream/handle/ bdcamara/18336/colleccao_leis_1823_parte2.pdf?sequence=2>. Acesso em: 25 out. 2016.

. Decisão 69, de 29 de abril de 1823. Manda tirar dos corpos de linha das Províncias um ou dois indivíduos para frequentarem nesta Corte as escolas do ensino mutuo pelo método de Lancaster. In Coleção das Leis do Império do Brasil de 1823 - parte III. Rio de Janeiro: Imprensa Nacional, 1887b. p. 52. Disponível em: <http://bd.camara.gov.br/ bd/bitstream/handle/bdcamara/18336/colleccao_leis_1823_parte3.pdf?sequence=3>. Acesso em: 28 out. 2016.

. Lei de 15 de outubro de 1827. Manda criar escolas de primeiras letras em todas as cidades, vilas e lugares mais populosos do Império. In Coleção da Leis do Império do Brasil de 1827 - parte primeira. Rio de Janeiro: Typografia Nacional, 1878. p. 71-73. Disponível em: <http://bd.camara.gov.br/bd/bitstream/ handle/bdcamara/18351/colleccao_ leis_1827_parte1.pdf?sequence=1>. Acesso em: 22 out. 2016.

Lei 16, de 12 de agosto de 1834. Faz algumas alterações e adições à Constituição Política do Império, nos termos da Lei de 12 de outubro de 1832. In: Coleção da Leis do Império do Brasil de 1834 - parte primeira. Rio de Janeiro: Typografia Nacional, 1866, p. 15-23. Disponível em: <http://bd.camara.gov.br/ bd/handle/bdcamara/18462>. Acesso em: 29 mar. 2017.

CASTANHA, André Paulo. A introdução do método Lancaster no Brasil: história e historiografia. In: SEMINÁRIO DE PESQUISA EM EDUCAÇÃO DA REGIÃO SUL, 9, 2012, Caxias do Sul. Anais... Caxias do Sul: Universidade de Caxias do Sul (UCS), 2012. p. 1-16. Disponível em: <http://www.portalanpedsul.com.br/admin/uploads/2012/ Historia_da_Educacao/Trabalho/04_34_32_1257-6384-1-PB.pdf>. Acesso em: 22 out. 2016.

Escolas Normais no Século XIX: um estudo comparativo. Revista HISTEDBR On-line, Campinas, n. 32 , p.17-36, dez. 2008a. Disponível em: <http://www.histedbr.fe.unicamp.br/revista/edicoes/32/art02_32.pdf>. Acesso em: 14 out. 2016.

. Iniciativas estatais de formação docente no Século XIX: as experiências da Escola Normal. In: SIMPÓSIO NACIONAL DE EDUCAÇÃO - XX SEMANA DA PEDAGOGIA, 2008, Cascavel. Anais... Cascavel: Universidade Estadual do Oeste do Paraná (Unioeste), 2008b, p. 1-15. Disponível em: <http://www.unioeste.br/cursos/cascavel/ pedagogia/eventos/2008/4/Artigo\%2008.pdf>.Acesso em: 06 nov. 2016.

O Ato Adicional de 1834 e a instrução elementar no império: descentralização ou centralização? 2007. 555f. Tese (Doutorado em Educação) - Universidade Federal de São Carlos, São Carlos, 2007.

ESCOLAS NORMAIS. In: WIKIPÉDIA, a enciclopédia livre. Flórida: Wikimedia Foundation, 2016. Disponível em: <https://pt.wikipedia.org/w/index.php?title=Escolas_ Normais\&oldid=44525661>. Acesso em: 16 out. 2016.

FERRARO, Alceu Ravanello. Analfabetismo e níveis de letramento no Brasil: o que dizem os censos? Educação e Sociedade, Campinas, v. 23, n. 81, p. 21-47, dez. 2002.

FOUCAULT, Michel. A arqueologia do saber. 7. ed. Rio de Janeiro: Forense Universitária, 2008.

GABLER, Louise. Escola Normal. Rio de Janeiro: MAPA - Memória da Administração Pública Brasileira, 2016. Disponível em: <http://linux.an.gov.br/mapa/?p=9352>. Acesso em 29 mar. 2017. 
LARA, Bortolanza. Guarda Nacional no Brasil Imperial, o Exército brasileiro antes e durante a guerra do Paraguai e os letrados ante a escravidão, 2014. Disponível em: <https://historicid.wordpress.com/2014/07/19/guardanacional-no-brasil-imperial-o-exercito-brasileiro-antes-e-durante-a-guerra-do-paraguai-e-os-letrados-ante-aescravidao/>. Acesso em: 31 out. 2016.

LE GOFF, Jacques. História e memória. Campinas, SP: Editora da Unicamp, 1990.

MACIEL, Lizete S. Bomura; NETO, Alexandre Shigunov. A educação brasileira no período pombalino: uma análise histórica das reformas pombalinas do ensino. Educação e Pesquisa, São Paulo, v.32, n.3, p. 465-476, set./dez. 2006.

MARCHELLI, Paulo Sergio. As minorias alfabetizadas no final do período colonial e sua transição para o império: um estudo sobre a história social e educação no Brasil. Educação Unisinos, São Leopoldo, v. 10, n. 3, p. 187-200, set./dez. 2006.

MARCÍlIO, Maria Luiza. O atraso histórico na educação: o que torna o ensino público brasileiro tão fraco? Braudel Papers, São Paulo, no 30, p. 1-15, 2001. Disponível em: <www.braudel.org.br/papers.htm>. Acesso em: 21 mar. 2017.

MARTINS, Angela M. Souza. Breves reflexões sobre as primeiras escolas normais no contexto educacional brasileiro, no Século XIX. Revista HISTEDBR On-line, Campinas, n. 35, p. 173-182, set. 2009. Disponível em: <http://www.histedbr.fe.unicamp.br/ revista/edicoes/35/art12_35.pdf>. Acesso em: 14 out. 2016.

OLINDA, Silvia R. Magalhães. A educação no Brasil no período colonial: um olhar sobre as origens para compreender o presente. Sitientibus, Feira de Santana, n. 29, p, 153-162, jul./dez. 2003.

PROVÍNCIA DO RIO DE JANEIRO. Decreto 10, de 10 de abril de 1835. Cria na Capital da Província do Rio de Janeiro uma Escola Normal. 1835. Disponível em: <http://www.infoiepic.xpg.com.br/hist_ato10.htm>. Acesso em: 06 nov. 2016.

. Lei 10 de 04 de abril de 1835. Cria uma Escola Normal na Capital da Província do Rio de Janeiro. In: Coleção de Leis, Decretos e Regulamentos da Província do Rio de Janeiro desde 1835. Niterói: Tipografia Niterói, 1839, p. 22-26.

RIBEIRO, Márden de Pádua. História da formação de professores no Brasil colônia e império. Temporalidades Revista de História, Belo Horizonte v. 7, n. 2, p. 410-434, maio-ago. 2015.

RODRIGUES, João Lourenço et al. Annuario do Ensino do Estado de São Paulo, 1907/1908. São Paulo: Publicação organizada pela inspetoria geral do ensino por ordem do Governo do Estado, 1908. Disponível em: <http://repositorio. ufsc.br/ xmlui/handle/123456789/96644>. Acesso em: 21 mar. 2017.

SÃO PAULO. Lei n. 34, de 16 de março de 1846. Dá nova organização às escolas de instrução primária, e cria uma Escola Normal. São Paulo: Assembleia Legislativa do Estado de São Paulo, [s. d.]a. Disponível em: <http://www.al.sp.gov.br/repositorio/ legislacao/ lei/1846/lei-34-16.03.1846.html>. Acesso em: 20 mar. 2017.

Lei 9, de 22 de março de 1874. Estabelece o Ensino Primário gratuito na Província. São Paulo: Assembleia Legislativa do Estado de São Paulo, [s. d.]b. Disponível em: <http://www.al.sp.gov.br/norma/?id=138072>. Acesso em: 20 mar. 2017.

SAVIANI, Demerval. Formação de professores: aspectos históricos e teóricos do problema no contexto brasileiro. Revista Brasileira de Educação, Rio de Janeiro, v. 14 n. 40, p. 143-155, jan./abr. 2009.

SCHAFFRATH, Marlene A. S. Escola Normal: o projeto das elites brasileiras para a formação de professores. In: ENCONTRO DO GRUPO INTERDISCIPLINAR DE PESQUISA EM ARTES DA FAP, 25 e 26 de setembro de 2008 , Curitiba. Anais... Curitiba: Faculdade de Artes do Paraná, 2008, p. 142-152. Disponível em: <http://www.fap.pr.gov. br/arquivos/File/Arquivos2009/Extensao/I_encontro_inter_artes/20_Marlete_Schaffrath.pdf>. Acesso em: 25 nov. 2016.

SCHUELER, Alessandra F. De mestres-escolas a professores públicos: histórias de formação de professores na Corte Imperial. Revista de Educação, Porto Alegre - RS, ano XXVIII, n. 2, p. 333-351, maio/ago. 2005.

SIQUEIRA, Lucília. Independência: história e historiografia. Estudos Avançados, São Paulo, v. 20, n. 57, p. 398-404, 2006. 


\section{RESUMO}

Este artigo tem como foco temático a discussão sobre as origens das políticas de formação de professores no Brasil que se deram ao longo do Período Imperial. Utiliza-se o método da pesquisa histórica realizada com base na análise de fontes primárias sobre as escolas de primeiras letras e as escolas normais criadas à época, valendo-se de contraposições críticas a textos contemporâneos sobre o tema contemplado. 0 estudo resulta na proposta de uma revisão dos marcos históricos do campo e conclui que somente há coerência em considerar uma política educacional como propriamente voltada para a formação de professores quando a questão curricular para tal propósito estiver posta explicitamente.

Palavras-chave: História da Formação de Professores. Escolas de Primeiras Letras. Escolas Normais.

\section{HISTORICAL ORIGINS OF TEACHER EDUCATION POLICIES IN BRAZIL (1823-1874)} ABSTRACT

This article has as its thematic focus the discussion about the origins of teacher education policies in Brazil that took place during the Imperial Period. The method of historical research is used based on the analysis of primary sources on the schools of first letters and the normal schools created at the time, utilizing critical oppositions to contemporary texts on the subject contemplated. The study results in the proposal of a revision of the historical landmarks of the field and concludes that there is only coherence in considering an educational policy as properly oriented towards the formation of teachers when the curricular question for that purpose is put explicitly.

Keywords: History of Teacher Education. First Letters Schools. Normal Schools.

\section{ORÍGENES HISTÓRICAS DE LAS POLÍTICAS DE FORMACIÓN DE PROFESORES EN BRASIL (1823-1874) RESUMEN}

Este artículo tiene como foco temático la discusión sobre los orígenes de las políticas de formación de profesores en Brasil que se dieron a lo largo del Período Imperial. Se utiliza el método de la investigación histórica realizada con base en el análisis de fuentes primarias sobre las escuelas de primeras letras y las escuelas normales creadas en la época, que se valen de contraposiciones críticas a textos contemporáneos sobre el tema contemplado. El estudio resulta en la propuesta de una revisión de los hitos históricos del campo. Se concluye que sólo hay coherencia en considerar una política educativa como propiamente orientada a la formación de profesores cuando la cuestión curricular para tal propósito está puesta explícitamente.

Palabras-clave: Historia de la formación de profesores. Escuelas de Primeras Letras. Escuelas Normales. 